\title{
Discrimination Between Mild and Severe Strains of Citrus Tristeza Virus by Fluorescent Antibody Technique
}

\author{
Atsushi SASAKI*, Tsuneo Tsuchizaki**, and Yasuo SAITo** \\ 佐々木 篤*・土崎常男**・斎藤康夫** : 蛍光抗体法による \\ カンキツ・トリステザ・ウイルスの弱, 強毒系の判別
}

In the previous paper ${ }^{1)}$, we reported the detection of citrus tristeza virus (CTV) in citrus tissues by fluorescent antibody technique, but the distribution of CTV in citrus was not studied. CTV has mild and severe strains, and the mild strain is not only harmless to some species or varieties of citrus, but also useful to prevent natural infection with the severe strain ${ }^{2)}$. This paper presents the results of immunofluorescence studies on the distribution of mild and severe strains of CTV in citrus.

Three strains of CTV, Hassaku dwarf strain (CTV-HD) ${ }^{3}$, , seedling yellows strain $(\mathrm{CTV}-\mathrm{SY})^{3)}$, and mild strain $(\mathrm{CTV}-\mathrm{M})^{3}$ ) were used in this experiment. In this paper, CTV-HD and CTV-SY are sometimes referred to as severe strain. Fluorescent antibodies against CTV prepared in previous tests ${ }^{1)}$ were also used in this experiment. This antiserum reacted with CTV-HD, CTV-SY and CTV-M to equal dilution end points in complement fixation tests.

Citrus tissues were cross-sectioned $20-30 \mu \mathrm{m}$ thick with a freezing microtome, fixed in $100 \%$ acetone for 30 to $90 \mathrm{~min}$ at $4 \mathrm{C}$, stained with fluorescent antibodies for 30 to $90 \mathrm{~min}$ at 33 to $37 \mathrm{C}$, washed in buffered saline for $30 \mathrm{~min}$ to $16 \mathrm{hr}$, and mounted in buffered glycerol for observation with the fluorescence microscope.

Five species of field grown citrus trees infected with 3 strains of CTV and a healthy Mexican lime plant (Citrus aurantifolia (Christm.) Swing.) grown in a greenhouse, were used to test the distribution of viral antigen in citrus during the winter season. Table 1 shows the distribution of CTV in citrus. Antigens could be detected in most of the tissues from infected plants. Large quantities of antigen were found in vascular bundles of fruit, petioles and twigs of all infected citrus. Especially, antigens were found to the greatest extent in vascular bundles of pericarps. On the other hand, only a few antigens were observed in major lateral veins and fibrous roots. No fluorescent staining was observed in healthy Mexican lime. Viral antigens were also found in various parts of a 10-day-old flower bud from a Hassaku plant (C. hassaku Hort. ex Tanaka) infected with CTV-M grown in a greenhouse. No conspicuous differences in number or condition of fluorescent

* Hiroshima Prefecture Fruit Tree Experiment Station, Kihara-cho, Mihara, Hiroshima, 72903, Japan, ** Institute for Plant Virus Reseach, Tsukuba Science City, Yatabe, Ibaraki, 300-21 Japan.

* 広島県果樹試験場

** 植物ウイルス研究所

1) Tsuchizaki, T., A. Sasaki, and Y. Saito (1978). Phytopathology 68:139-142. 2) Müller, G. W. and A. S. Costa (1968). In J. F. L. Childs (ed.) Proc. 4th Conf. Intenrn. Organization Citrus Virol. Gainesville, Univ. Florida Press: 71-82. 3) Sasaki, A. (1974). Studies on Hassaku dwarf. Special Bull. Fruit Tree Exp. Sta. Hiroshima Prefecture 2:1-106. 
cells were observed among citrus species or virus strains. Thus, it is assumed that most of tissues with phloem could be used for the detection of CTV by the fluorescent antibody technique. However, petiole might be most useful tissue for detection of CTV because of its availability from plants of any age or size and of its easy handling.

Table 1. Detection of specific fluorescent phloem cells in various tissues from several citrus species infected with citrus tristeza virus (CTV).

\begin{tabular}{|c|c|c|c|c|c|c|c|}
\hline \multirow{3}{*}{ Tissue } & \multicolumn{7}{|c|}{ Frequency of fluorescent cells ${ }^{a)}$} \\
\hline & \multirow{2}{*}{$\begin{array}{l}\left.\text { CTV-M }{ }^{\mathrm{b}}\right) \\
\text { Hassaku }\end{array}$} & \multicolumn{5}{|c|}{ CTV-S $\mathrm{S}^{\mathrm{b}}$} & \multirow{2}{*}{$\begin{array}{l}\text { Healthy } \\
\text { Mexican } \\
\text { lime }\end{array}$} \\
\hline & & Hassaku & W.navel $\left.{ }^{C}\right)$ & $\begin{array}{l}\text { Natsu-C) } \\
\text { daidai }\end{array}$ & $\begin{array}{l}\text { Satsuma } \\
\text { mandarin }\end{array}$ & lemon & \\
\hline Petiole & +++ & ++++ & +++ & +++ & ++ & ++++ & - \\
\hline Midvein & ++ & +++ & +++ & ++ & ++ & ++ & - \\
\hline $\begin{array}{l}\text { Major lateral } \\
\text { vein }\end{array}$ & + & ++ & + & + & + & + & \\
\hline Twig & +++ & +++ & +++ & +++ & ++ & ++++ & - \\
\hline Stem bark & +++ & ++ & & & +++ & & \\
\hline Fibrous root & - d) & $+e)$ & & & $\left.+^{f}\right)$ & & \\
\hline $\begin{array}{l}\text { Vascular } \\
\text { bandle of } \\
\text { pericarp }\end{array}$ & ++++ & ++++ & ++++ & ++++ & ++++ & ++++ & - \\
\hline Flower bud & & & & & & & \\
\hline ovar & ++ & & & & & & \\
\hline style & +++ & & & & & & \\
\hline anther & ++ & & & & & & \\
\hline petal & ++ & & & & & & \\
\hline peduncle & ++ & & & & & & \\
\hline
\end{tabular}

a) average number of specific fluorescent cells observed in 5 to 20 sections, $-: 0,+: 1-10$, $++: 11-50,+++: 51-90,++++:>91$.

b) CTV-M : mild strain of CTV, CTV-S : severe strain of CTV.

c) W. navel = Washington navel:C. sinensis Osb. var. brasiliensis Tanaka, Natsudaidai : C. nat sudaidai Hayata.

d) Trifoliate orange : Poncirus trifoliata Raf. was used as rootstock.

e) Natsudaidai was used as rootstock.

f) Yuzu : C. junos Sieb. ex Tanaka was used as rootstock.

To study the progression in the development of viral antigens in young shoots of citrus, petioles and twigs were collected from CTV-infected or CTV-free Hassaku plants grown in a greenhouse at intervals of 7 or 30 days after sprouting. Viral antigens were present in most of the diseased tissues examined (Table 2). Number of the fluorescent cells was maximum at 21 to 30 days after sprouting, and decreased after 60 to 90 days. Number of the fluorescent cells in petioles infected with CTV. $\mathrm{M}$ was less than that in petioles infected with CTV-HD 21 to 90 days after sprouting. In addition, dotted specific fluorescent cells were observed in phloem tissues infected with CTV-M (Fig. 1, a), and several fluorescent cells formed clusters 14 to 30 days after sprouting in phloem tissues infected with CTV-HD (Fig. 1, b). These diffe- 
Table 2. Detection of specific fluorescent cells (Fl) and clustered ones (Cl) in phloem of young petioles and twigs from Hassaku plants infected with citrus tristeza virus (CTV).

\begin{tabular}{|c|c|c|c|c|c|c|c|c|c|c|c|c|c|c|c|}
\hline \multirow{4}{*}{$\begin{array}{c}\text { Strain } \\
\text { of } \\
\text { virus }\end{array}$} & \multirow{4}{*}{ Tissue } & \multicolumn{14}{|c|}{$\begin{array}{l}\text { Frequency of fluorescent phloem cells }(\mathrm{Fl})^{\mathrm{b})} \text { and occurrence } \\
\text { of clusters of fluorescent cells }(\mathrm{Cl})^{\mathrm{c})}\end{array}$} \\
\hline & & \multicolumn{14}{|c|}{ Days after sprouting } \\
\hline & & \multicolumn{2}{|c|}{0} & \multicolumn{2}{|c|}{7} & \multicolumn{2}{|c|}{14} & \multicolumn{2}{|l|}{21} & \multicolumn{2}{|l|}{30} & \multicolumn{2}{|l|}{60} & \multicolumn{2}{|c|}{90} \\
\hline & & $\mathrm{Fl}$ & $\mathrm{Cl}$ & F1 & $\mathrm{Cl}$ & $\mathrm{Fl}$ & $\mathrm{Cl}$ & $\mathrm{F} 1$ & $\mathrm{Cl}$ & $\mathrm{Fl}$ & $\mathrm{Cl}$ & F1 & $\mathrm{Cl}$ & Fl & $\mathrm{Cl}$ \\
\hline CTV-M & $\begin{array}{l}\text { Petiole } \\
\text { Twig }\end{array}$ & + & - & $\begin{array}{l}++ \\
++\end{array}$ & - & $\begin{array}{l}++ \\
+++\end{array}$ & - & $\left|\begin{array}{l}++ \\
++++\end{array}\right|$ & - & $\left|\begin{array}{l}++ \\
++++\end{array}\right|$ & - & $\begin{array}{l}+ \\
++\end{array}$ & - & $\begin{array}{l}+ \\
++\end{array}$ & - \\
\hline CTV-HD & $\begin{array}{l}\text { Petiole } \\
\text { Twig }\end{array}$ & + & - & $\begin{array}{l}++ \\
++\end{array}$ & $\begin{array}{l}- \\
+\end{array}$ & $\begin{array}{l}++ \\
+++\end{array}$ & $\begin{array}{l}+ \\
+\end{array}$ & $\begin{array}{l}+++ \\
++++\end{array}$ & $\begin{array}{l}+ \\
+\end{array}$ & $\begin{array}{l}++++ \\
++++\end{array}$ & $\begin{array}{l}+ \\
+\end{array}$ & $\begin{array}{l}+++ \\
++\end{array}$ & $\begin{array}{l}+ \\
-\end{array}$ & $\begin{array}{l}++ \\
++\end{array}$ & $\begin{array}{l}+ \\
+\end{array}$ \\
\hline Healthy & $\begin{array}{l}\text { Petiole } \\
\text { Twig }\end{array}$ & - & - & $\begin{array}{l}- \\
-\end{array}$ & - & - & $\begin{array}{l}- \\
-\end{array}$ & $\begin{array}{l}- \\
-\end{array}$ & $\begin{array}{l}- \\
-\end{array}$ & $\begin{array}{l}- \\
-\end{array}$ & - & - & $\begin{array}{l}- \\
-\end{array}$ & $\begin{array}{l}- \\
-\end{array}$ & - \\
\hline
\end{tabular}

a) CTV-M: mild strain of CTV, CTV-HD: Hassaku dwarf strain of CTV.

b) average numbers of specific fluorescent cells observed in 5 to 15 sections. $-: 0,+: 1-10,++: 11-50,+++: 51-90,++++:>91$.

c) + : clusters of fluorescent cells were present, - : absent.

rences between CTV-M and CTV-HD were observed also in Spring, Summer and Autumn flushes from field grown Hassaku trees. These results suggest that CTV. HD multiplies in phloem cells and is transmitted to neighboring phloem cells more rapidly than CTV-M. Some of the clustered fluorescent cells often became necrotic. Such necrotic cells were never found in petioles infected with CTV-M. Similar experiments were carried out in greenhouse grown 3 other species of citrus, Satsuma mandarin (C. unshiu Marc.), Lisbon lemon (C. limon (L.) Burm.) and Rough lemon (C. jambhiri Lush.), in which stem pitting was not generally induced by CTV infection. In Lisbon lemon and Rough lemon, similar results were obtained. In Satsuma mandarin, however, a few fluorescent cells were found in tissues infected with CTV. $\mathrm{M}$, and many fluorescent cells, which formed few clusters, were found in tissues infected with severe strains. Since conspicuous differences in number of fluorescent cells or formation of clusters of fluorescent cells were observed among virus strains, it was suggested that, in general, it may be possible to discriminate between mild and severe strains in petioles and twigs observed 14 to 30 days after sprouting by using the fluorescent antibody technique.

Indexing for CTV is currently being done by lime test, and mild and severe strains are differentiated on the basis of the symptoms which they produced on lime. However, the lime test requires considerable long time and greenhouse space. The fluorescent antibody technique may be useful for rapid detection of mild and severe strains of CTV by use of young petioles or twigs from citrus plants.

(Received January 21, 1978) 

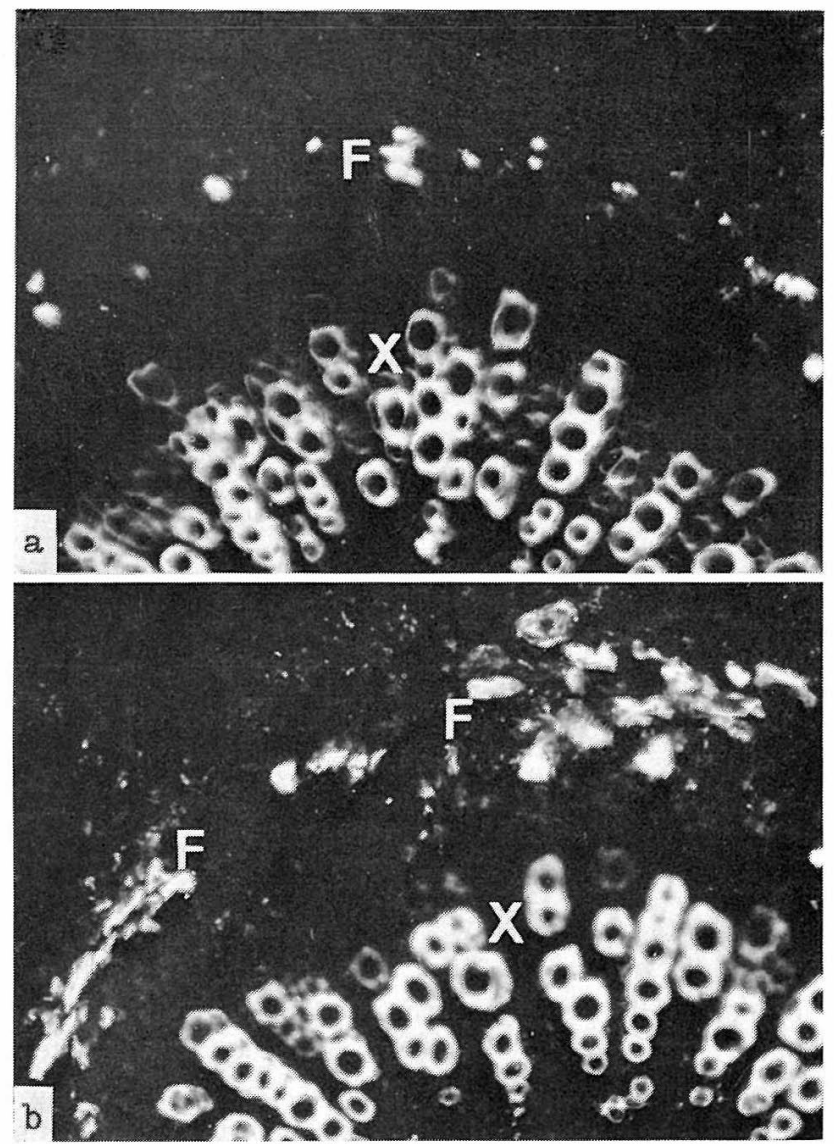

Fig. 1. Fluorescence micrographs of CTV in 30-day-old petioles of Hassaku plants. a) Sample infected with a mild strain. b) Sample infected with a severe strain. Note fluorescence appearing in clusters or forming masses.

(F: fluorescence, $\mathrm{X}$ : xylem) 